論文

\title{
Chemorheological Properties of Uncrosslinked Polybutadiene
}

by

\author{
Kozo Arai and Yuji NaIto \\ (Japan Synthetic Rubber Co. Ltd., Tokyo Research Laboratory, \\ 7569 Ikuta, Tama-ku, Kawasaki, Kanagawa 214)
}

The chemorheological properties of purified uncrosslinked polybutadiene rubber were examined under various conditions. Intermittent stress relaxation measurements were performed for specimen of various thermal histories in unstretched conditions; i.e., various combinations of temperature and exposure time interval ranging from $30^{\circ} \mathrm{C}$ to $245^{\circ} \mathrm{C}$ and from $0 \mathrm{~min}$ to $150 \mathrm{~min}$, respectively. The time scale of the measurements, ranging from $0.01 \mathrm{sec}$ to $10 \mathrm{sec}$, was so short compared with that of unstretched states that one can neglect the chemical reaction under stretched states. This method was found good for measuring the effects of chemical and physical relaxation separately. The effect of chemical reactions can be examined by using the relaxation modulus as a function of exposure time.

In spite that the specimens were held in the nitrogen gas atmosphere, remarkable gelation took place at higher temperatures. Dependence of isochronous values of relaxation moduli on the exposure time suggested the existence of two types of gelation reaction. One was a rapid reaction observed at short exposure time and the other was a slow one at relatively long exposure time. From the Arrhenius plots, two types of activation energy of gelation were observed. The activation energy, ranging from 24 to 36 and from 0 to $5 \mathrm{kcal} / \mathrm{mol}$, showed the marked time dependence. It may correspond to the difference in molecular weight and molecular weight distribution of the sample. The measurements were also performed on the infrared spectroscopy and swelling.

\section{未加硫 BR のケモレオロジー的研究}

\author{
新 井洸三・内藤 雄 二**
}

(原稿受理：1978年12月21日)

\section{1. 緒}

\section{言}

各種材料の化学的変化を機械的性質の变化を通じて捕えるす法 は, 材料評価法の常とう手段として古くから用いられて来たが, その後 Tobolsky1) によってレオロジーの知見を導入することに より, 高分子物質の研究に有効であることが明らかにされた。こ

* 日本合成ゴム株式会社東京研究所川崎市多摩区生田7569
の研究分野はケモレオロジーと呼ばれ, 主としてゴムを対象とし て多くの研究がなされて打り, 近年に至っても依然として多用さ れている，例えば，ポリマーに対する要求水準の高度化に伴う耐 熱性の評価法や，酸化防止剤をはじめとする各種添加剤の作用機 構の研究並飞評価法として, 他の研究手段では得られ多くの知 見が得られている2.

これまで報告されているこの分野の研究の汪とんどすべてが， 
加硫ゴム等架橋ポリマーを効象として扣り，未架橋物へ適用した 例は極めてまれである ${ }^{3)}$. その最大の理由は化学緩和比べて物 理緩和が大きく，前者のみを独立に取り出寸事が困難なためであ り，未架橋物汇関する知見が不必要であったためではない，

未架橋物冲架橋物沉比してポリマーそのものの特性をより大き く反映するので学問的には重要であり, 更に架橋物の解析を行う にあたり，架橋点扔よびそれが原因で新たに生じた特徵に着目し て論じる場合の基礎データとしての意味も重要である。

化学緩和と物理緩和が同程度起こる場合に，ケモレオロジ一的 手法を適用するとすれば，両者の容与を明確に分離する必要があ ろ. 一つの方法として, 真空中での応力緩和測定を行った Veith 等4の例があげられるが，必ずしも充分なものではない，Tobol$\mathrm{sky}^{11}$ は分子切断とともに架橋が生じる型の熱劣化過程に括いて， これらを分離する手法として Intermittent 法を提唱した。これら はいずれも目的に応じて異なる型の実験を行い，結果を比較して 目的とする情報のみを単離するための方法である。

化学緩和と物理緩和を分離する他の方法として，応力緩和の測 定時間を短縮する。つまり短時間領域の測定を行うことが考えら れる.すなわち, これは物理緩和に比し化学緩和が無視しうる程 度の短時間内に測定を終了することにより，前者のみを分離する ものであり, 後者については試料熱履歴を与えつつ前述の物理 緩和の測定を繰り返し行い，その熱履歷時間依存性より推定され る.この方法はIntermittent 法汇酷似しているが，断続的に行わ れる各測定のタイムスケールがすべて等しく短時間である点が根 本的に異なる，短時間域の測定を行いらるということは, 例えば 上述のほかに熱可塑性樹脂の流動域の測定にも応用しらることを 意味して扣り，その点からも意義は大きい。

筆者らは，特に短時間領域の緩和現象の記録に有効なディジタ ル式記録計 (“LOGTIMER”) を) 開発し，これを利用して各種ポ リマーの応力緩和挙動を調べつつある。ここでは，高温下に执け る未架橋ポリブタジエンゴムの短時間域の測定を利用して，ヶモ レオロジー的解析を行った例について報告する.

\section{2. 実 験}

\section{$2 \cdot 1$ 試料}

試料として高シスポリブタジェン（日本合成ゴム株式会社製,

JSR BR01，ベースポリマー*1) を用いた。

上記試料溶液をトルエンで希釈し約 $10 \%$ 溶液を調製し，G 3 ガ ラスフィルターで不溶分をろ別した後，ろ液を大過剩のメタノ一 ル中で再沈させた，得られた固形物を真空乾燥してベンゼン溶液 とし，凍結乾燥法によりポリマー精製試料を得た。得られた試料 のトルエン中, $30^{\circ} \mathrm{C}$ と扣ける固有粘度は約 2.8 であった。

凍結乾燥により得られた試料を手早くロールで予備成形した後, モールドにはさみ約 $80^{\circ} \mathrm{C} て ゙ 10$ 分間プレス成形することにより，70 $\times 70 \times 3 \mathrm{~mm}$ のシートを得た。 このシートは使用時以外は窒素ガ ス下でストッカー中に保存した.

\section{$2 \cdot 2$ 応力緩和測定装置}

短時間域の応力緩和測定に用いた装置の 概略を Fig. 1 亿示す.

*1 本実験に先だち行われた予備実験の結果, 試料中に残存する少量 の酸化防止剂が測定結果に影響を及ぽすことが明らかになったの で, 重合後停止剂のみを添加し, 酸化防止剂は含有しない試料を 特別に作製した。
本報告では化学緩和の影響を除去するため，0.01秒から緩和挙動 を観察することを目標として測定装置を检討した。短時間域から の測定を行うためには，ひずみ印加に要する時間を充分短くする 必要があり ${ }^{6)}$, そのために最も確実な方法は変形付与速度を高め

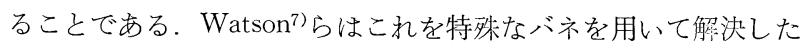
が，現状では通常の力法により充分高速（例えば，10メートル/ 秒）の伸長変位機欒を実現することは困難であり，また装置や応 力検出部のレスポンス, 変形付与直後の振動など過渡現象が問題 となる，筆者らは平行平板サンドイッチ型の試料保持究の採用に より, 通常の変形付与手段によっても充分短時間内にひずみの付 与が可能であり，しかも試料部を含む测定系の固有振動数が測定 のタイムスケールに比し充分に高く，得られる結果が振動の影響 を受けないといら利点があることなどを確認した。また，この形 式は試料の保持が簡単であるにもかかわらず，流動状態に打いて すら自重の影響が無視できて正確な測定が可能であり，高温と拉 けるポリマーの短時間域の測定には最適のものである。

変形付与機構には市販のエアーシリンダーを用いた. 応力㭘出 には市販のロードセル拉よび直流型増幅器を使用した（共和電業 製).

\section{$3 \cdot 3$ 応力緩和用記録計}

応力緩和の測定は，通常時間の対数の関数として取り报われる. したがって, 短時間領域に执ける応力緩和挙動を追跡する場合, 例えば，市販のサンプリングメモリーを用いることも考えられる が，これは単に等時間隔でサンプリングするため不充分である.

筆者らは, Fig. 2 に示すような緩和現象の測定に便利な特殊 な記録計を開発し実験に使用した。この記録計の原理を簡単に説 明する。すなわち，緩和現象を表すアナログ入力信是 Iは，フィ ルター NF, 増幅器 $\mathrm{A}$ 経て, コンバーター $\mathrm{A} / \mathrm{D}$ によディジタ ル変換される。データは $\mathrm{A} / \mathrm{D}$ コンバーターの変換時間（約 50 $\mu \mathrm{sec})$ ごとに変換されるが，メモリーMVはダート Gが開いた時 にのみ記憶される。このゲートは刘数等時間間隔パルス発振器 LT からのパルス信号により制御される。すなわち,メモリ一に

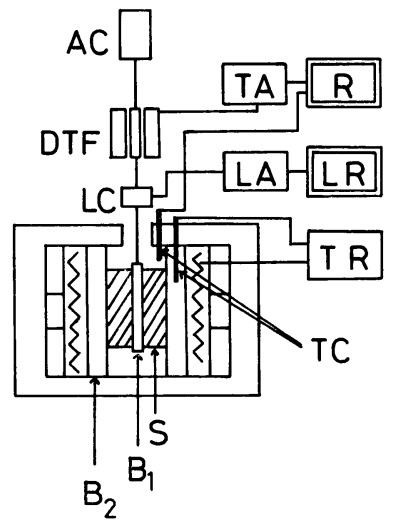

Fig. 1 Block diagram of the relaxation measurement equipment.

$\mathrm{S}$;specimen, $\mathrm{B}_{1}$; inner plate, $\mathrm{B}_{2}$; outer plate, $\mathrm{TC}$; thermo couple, $\mathrm{AC}$; air cylinder, DTF; differential transformer, LC; load cell, TA; amplifier for DTF, LA; amplifier for LC, R; recorder, TR; temperature regulator, $L R$; recording equipment for relaxation phenomena ("LOGTIMER"). 


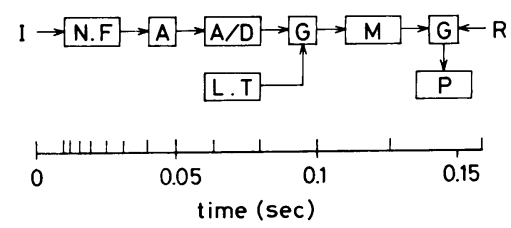

Fig. 2 Block diagram of the recording equipment and a set of pulses generated by LT.

I; input signal, NF; noise filter, A; amplifier, A/D; analogue to digital converter, G;gate, $\mathrm{M}$; digital memory, $\mathrm{R}$; readout command signal, $\mathrm{P}$; printer, LT; logarithmic timing pulse generator.

は対数的に等間間隔のデータのみが選択的にディジタル化され貯 蔵されることになる。戍の下部に示したスケールは，0.01秒から 対数時間(秒)で 0.1 ごとに LT から発振されるパルス列の最初の 部分を意味する. データは測定終了後必要に応じ読み出し指令信 号 Rを外部から与えることにより，プリンター P に印字記録され る。

本記録計 (“LOGTIMER”) の特徵は, 対数等洔間間隔のパル ス発振器, メモリー，プリンターなどを組み合わせたことにより， これまでの記録手段では不可能な短時間領域から長いタイムスケ ールにわたって, 緩和現象の記録に必要なデータのみを選択的に 記録しうることにある.

\section{$2 \cdot 4$ 応力緩和測定}

応力緩和の測定は, $2 \cdot 2$ および $2 \cdot 3$ 項に記した装置を用いて 種々の条件下で行った。代表的な実験条件をむとめて記す。

測定時間 $\quad 0.01 \sim 10$ 秒

熱履歴温度 $\quad 30 \sim 244.5^{\circ} \mathrm{C}$ (䨌团気, $\mathrm{N}_{2}$ ガス)

熱履歴時間 $\quad 0 \sim 150$ 分

測定頻度 升温後 $0,1,2,5,10,20,30,60,90,120,150$ 分

この他, 試料の熱特性の概略を知る目的で, $0.95^{\circ} \mathrm{C} / \mathrm{min}$ 程度 の定速昇温下での緩和測定も行った.

\section{$\mathbf{2} \cdot \mathbf{5}$ 膨潤実験}

加熱によりダル化した試料の膨潤度测定を行い，加熱条件と膨 潤比, ゾル分率などの相関を調ベた（条件，ベンゼン中， $30^{\circ} \mathrm{C}$, 48時間).

$2 \cdot 6$ 赤外吸収スペクトル

ゲル化した試料を $\mathrm{CS}_{2}$ で膨潤させ， $\mathrm{NaCl}$ 板にはさみ測定した.

\section{3. 結果および考察}

\section{$3 \cdot 1$ 定速昇温下における応力緩和}

試料の熱劣化挙動の大略を知る目的で, 約 $0.95^{\circ} \mathrm{C} / \mathrm{min}$ の定速 昇温下に扣いて, 断続的に短時間領域の応力緩和測定を行った. 結果をFig. 3 亿示す. 約 $30^{\circ} \mathrm{C}$ から $130^{\circ} \mathrm{C}$ までは通常の線型域の結 果と何ら変わることなく, 時間温度換算が可能で合成曲線が得ら れた。図中実線で示したのは $130^{\circ} \mathrm{C}$ 基準温度とした合成曲線で ある。

$130^{\circ} \mathrm{C}$ 以上では長時間側の剛性率の增大が起こり, 時間温度換 算が不可能になる。この傾向は時間（温度）とともに次第に顕著 となり, 緩和速度は減少する。 $130^{\circ} \mathrm{C}$ 以上に扣いて, 試料は熱少 化（ゲル化）を起こしていることは明らかであり, しかも測定時 間が一測定当たり最大 10 秒で, 応力解放時の時間に比し充分短い ので測定時間中に和けるゲル化は汪とんど無視しうる。つまり

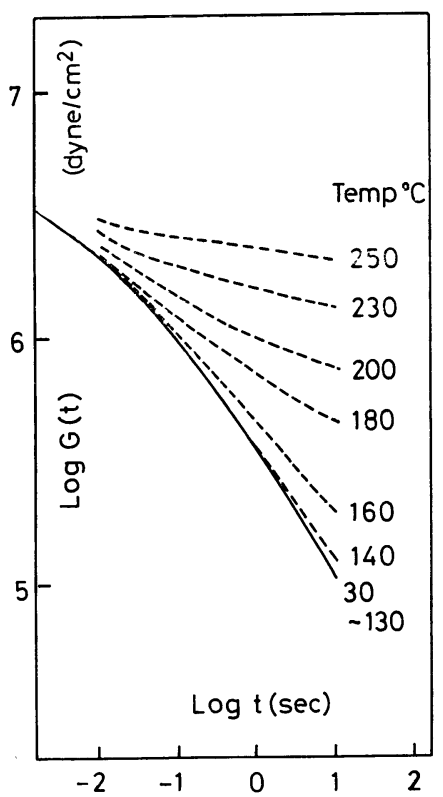

Fig. 3 Relaxation modulus of uncrosslinked polybutadiene at temperatures continuously increasing at rate of $0.95{ }^{\circ} \mathrm{C} / \mathrm{min}$.

Fig. 3 に示した各々の曲線は物理緩和のみを表して括り, 化学 緩和（この場合, ゲル化）はこれらの曲線の相互比較により求め られる。

ここで示した定速升温下の実験は, 厳密な意味では温度が平衡 状態にはなく問題があるが，温度特性の概略を知るためには測定 時間が短く便利な方法である.

\section{$3 \cdot 2$ 高温における応力緩和（測定温度依存性）}

高温に扣ける応力緩和挙動の測定温度依存性を Fig. 4 に示し た.

各曲線は表示した各温度に達してから約 2 分後に測定を行った もので, 今後熱履歴時間について論じる場合にはこの時間を基準 とする，高温に括いてはとれぞれの測定温度に達する間に，ゲル 化が始まっていることが明らかである。 このような温度範囲にお

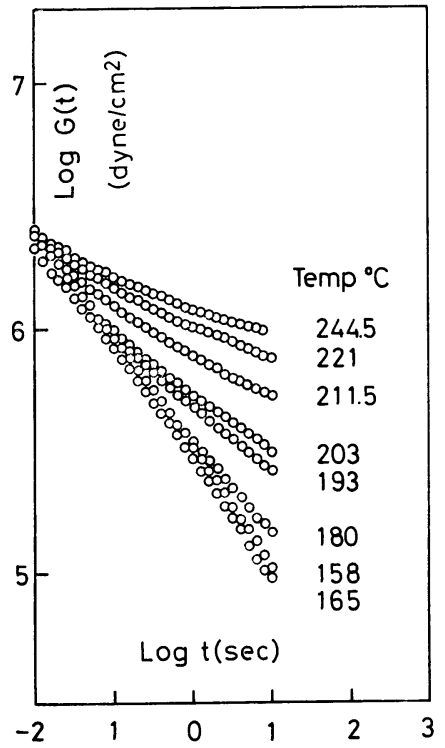

Fig. 4 Relaxation modulus at various temperatures. 
いては窒素気流下でもグル化反応が起こることは既に報告されて (るる).

\section{3・3 高温における応力緩和（熱履歴時間依存性）}

一定温度下に試料を置いた場合の緩和举動の経時変化（熱履歴 時間依存性）をFig. 5，6 飞示す。この測定は前述の上5に Tobolsky ら ${ }^{1)}$ の断続法と酷似しているが，本報告の方法で間欠的

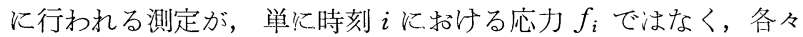
の時刻で独立した観測時間依存性を有する緩和応力 $G(t)$ である 点が，従来の断続法とは全く異なる．個々の測定の所要時間は最 大10秒で化学緩和が無視できること．化学緩和は同一温度に执い て熱履歴を受けた時間ごとのデータより得られることなどは，前 項で述べたと同様である，従来のケモレオロジーの手法と賁なり， 連続法とのデータの此較を必要とせず，同一試料を用いるので試 料間のばらつきが問題にならず, しかも粘弾性的に綮密に同一な タイムスケール間でデータの比較を行うものであるから，物理的 意味はより明確である。

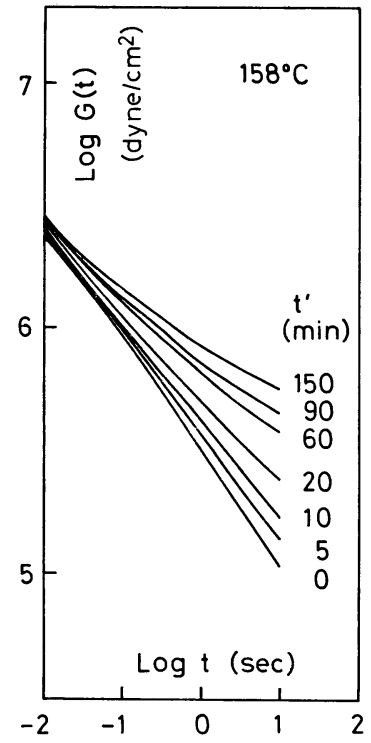

Fig. 5 Change in relaxation modulus with exposure time at $158^{\circ} \mathrm{C}$.

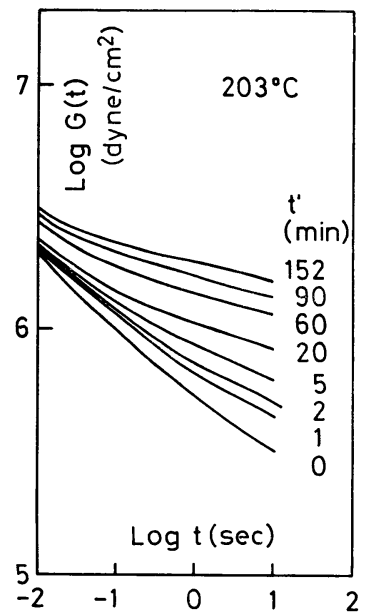

Fig. 6 Change in relaxation modulus with exposure time at $203^{\circ} \mathrm{C}$.

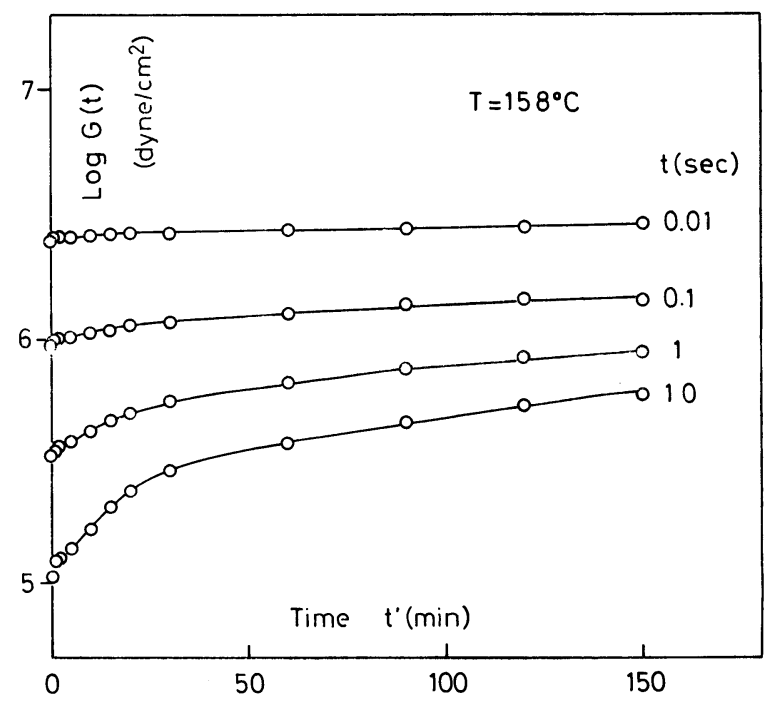

Fig. 7 Isochronous plots at $158^{\circ} \mathrm{C}$. Relation between relaxation modulus and exposure time.

熱履歴を受けた場合，応力緩和曲線は時間とともに高剛性率側 ヘシフトすると同時に長時間側の值が增し勾配が小さくなるが, 高温に捛ける程, 短時間域 (例えば0.01秒) の剛性率の熱履歴時 間依存性が大ぎ，勾配の変化率は小さいという特徽が見られる.

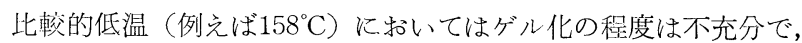
分子量分布は広くなったものの 0.01 秒のタイムスケール飞効応す る短い架橋点間鎖はあ屯り增大していないるのと思われる。これ に対し Fig. 6 の結果は $200^{\circ} \mathrm{C}$ 以上では，ゲル化は時間とともに著 しく進行し，架橋点間分子量か 0.01 秒で充分観測しらるレベルに 遘していることを示している.

\section{$3 \cdot 4$ 応力緩和の等時プロット（観測時間依存性）}

前項で示した $158^{\circ} \mathrm{C} に$ 拈けるデータを熱履歴時間の関数として, 観測時間ごとの等時プロットを行った結累を Fig. 7 飞示す.

このプロットは，Tobolsky らの断続法のプロットに相当する 乞考光られるが，極めて短時間領域の等诗データとい5特徴があ る. 図から熱履歴時間の増大とともに $\{G(0.01) / G(10)\}$,つまり 剛性率の観測時間内の変化率が小さくなること (勾配の 減少), それぞれの等時プロットに扮いて比較的短い熱履歴時間の初期段 階に和いて変化率が大きいが，時間の経過とともに一定の勾配の 直線に収れんすることなどが明らかになった。この剛性率の変化 率は観測時間が長い程顕著である。この二種の勾配の意味は明ら かではないが，観測のタイムスケールとかなり強い相関があるこ とから，少なくともそれぞれに応じた分子量（架橋点間分子量） の生成と関係づけられることは明らかである．観測時間をより長 くすることにより，ゲル化の早い時期から現象を観察しうる可能 性があるが，測定時間内の化学緩和の扣それが生じて来るので， あまり長時間にわたる測定は適当でない。

\section{$3 ・ 5$ 応力緩和の等時プロット（熱劣化温度依存性）}

$158^{\circ} \mathrm{C}$ から $244.5^{\circ} \mathrm{C}$ までの観測時間 1 秒に搞ける等時プロットの 熱履歴時間依存性をFig. 8 に示した。いずれの温度においても ゲル化に伴う剛性率の変化が見られるが，剛性率の值は熱履歴温 度, 時間とともに増大寸る．初期勾配は，はじめ温度とともに增 大するが，約 $200^{\circ} \mathrm{C}$ 付近を境として 再び減少するようである.

Fig. 7 扣よび Fig. 8 などで得られた曲線は，断続法の等時プロ 


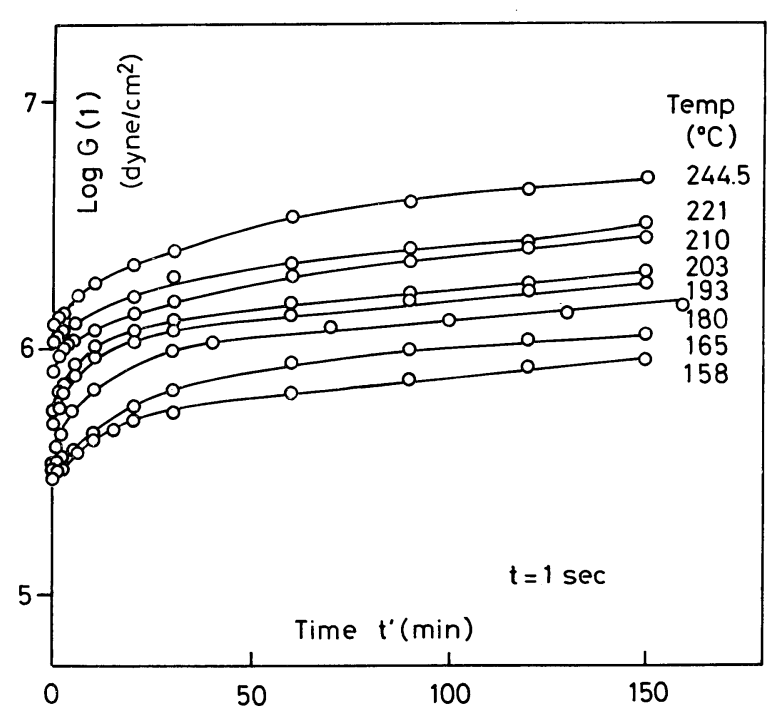

Fig. 8 Isochronous curves at $t=1 \mathrm{sec}$ at various temperatures.

ットであるが，これらはとれぞれ初期と終期に分けて直線近似， つまり Maxwell 型の近似をしうるような形状をしている。すな わち，

$$
\begin{aligned}
& G\left(t, t^{\prime}\right)=G_{1}(0) \exp \left[-\left(-k_{1}\right) t^{\prime}\right] \\
& G\left(t, t^{\prime}\right)=G_{2}(0) \exp \left[-\left(-k_{2}\right) t^{\prime}\right]
\end{aligned}
$$

ここで, 指数関数内の変数をー $\left(-k_{1}\right)$ のよ5飞置いたのは, 直 線が正勾配であるにもかかわらず Maxwell type の減衰曲線を適 用したための形式的な措置である. 同曲線を適用した場合 $\left(-k_{1}\right)$, $\left(-k_{2}\right)$ は切断反応の速度定数であるので， $k_{1}, k_{2}$ はそれぞれゲル 化の反応定数汇刘応寸ると考光られる.上式で $t^{\prime}$ は熱劣化の履歴 時間であるが，緩和の観測時間 $t$ とまぎらわしいので区別した。

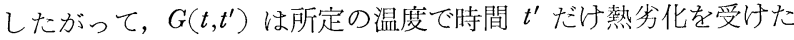
場合の観測時間 $t$ 亿括ける緩和剛性率を意味する.

各測定温度，観測時間ごとに $k_{1}$ および $k_{2}$ を求め Arrhenius プロット

$$
k_{i}=A \exp \left(-E_{i} / R T\right)
$$

を行った結果をFig. 9 に示した。 ここで $R, T$ はそれぞれ気体 定数, 熱履歴温度であり， $E_{i}$ は活性化エネルギーである. 各時 刻ごとの $E_{1}$ 抢よび $E_{2}$ の值を Table 1 亿示す.

このプロットの物理的意味は必ずしも明らかでないが,

1) $E_{1}, E_{2}$ とも観測のタイムスケール依存性がある。すなわち, 観測時間が長くなるにつれ小さくなる（勾配の温度依存性が減 少).

Table 1 Activation energy of gelation at high temperatures

\begin{tabular}{ccc}
\hline$t(\mathrm{sec})$ & $E_{1}(\mathrm{kcal} / \mathrm{mol})$ & $E_{2}(\mathrm{kcal} / \mathrm{mol})$ \\
\hline 0.01 & 36.2 & 4.94 \\
0.1 & 32.4 & 2.56 \\
1 & 26.9 & 1.83 \\
10 & 23.6 & $\sim 0$ \\
\hline
\end{tabular}

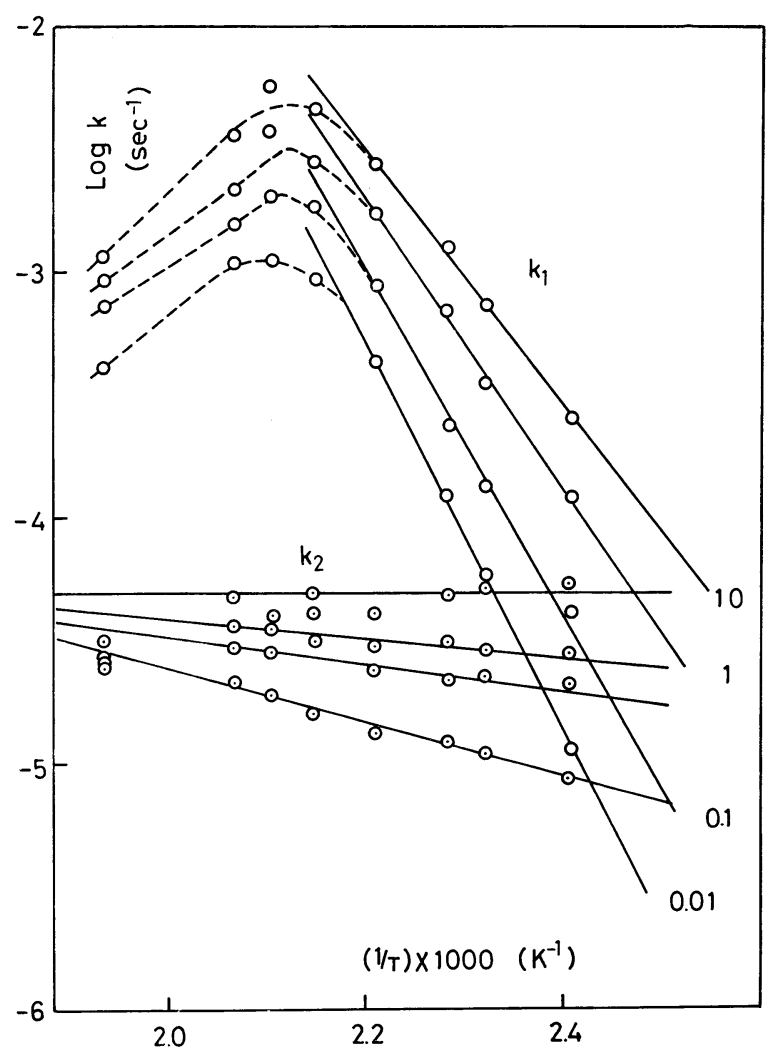

Fig. 9 Arrhenius plots. $k_{1}$ and $k_{2}$ are calculated from initial and final slope in Fig. 7 and 8 , respectively.

2) $E_{1}$ は $E_{2}$ よりかなり大.

3） $190^{\circ} \mathrm{C}$ 以下では $k_{1}, k_{2}$ とも Arrhenius プロットが可能である. 4） $190^{\circ} \mathrm{C}$ 以上では直線性から外机る。

等のことが明らかになった。

ポリブタジェンゴムに批ける熱劣化挙動に関しては山下らの総 説がある ${ }^{9)}$. 一般に 1,4 ポリブタジェンでは開始反応は比較的起 こりにくいと考兄られるが，一度発生するとラジカルは不安定な ため, 他のゴム分子の二重結合に付加する等により架橋がひき起 こされる可能性が強い，例えば，代表的な反応として

$$
\begin{aligned}
& \sim \mathrm{CH}_{2}-\mathrm{CH}=\mathrm{CH}-\mathrm{CH}_{2} \sim \stackrel{\mathrm{R} .}{\longrightarrow} \sim \mathrm{CH}_{2}-\mathrm{CH}-\mathrm{CH}-\mathrm{CH}_{2} \sim
\end{aligned}
$$

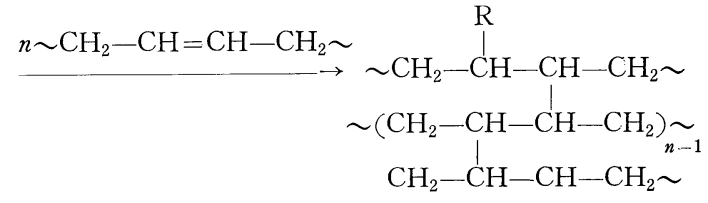

のような過程により架橋（ゲル化）が進行すると言われている.

$E_{1}$ は測定のタイムスケール依存性を有するという点では $E_{2}$ と 同様であるが，值ははるかに大きく約 $30 \mathrm{kcal} / \mathrm{mol}$ に達する。 こ の值は Tobolsky ら ${ }^{11}$ とよって求められた架橋天然ゴム, あるい は村上ら ${ }^{10)}$ によって求められた高シスポリブタジェンゴムの熱劣 化の活性化エネルギーと同程度であり，極めて大きいと言える. ここで示したように窒素気流中に括ける熱劣化に招いて, 初期の 十分間程度の間に起こる急速な反応は何に起因するのであろらか. 
$\mathrm{R}$ •として過酸化物などが考兄られるが，この場合には精製した 試料なのでその様な可能性は少なく，代わりに熱によりポリマー の一部から水素が引き报かれた遊離基などの可能性もある。この ようなポリマーラジカルが生成するためには，エネルギー的にか なり大きなものを必要とするが, 構造の不安定な部分, つまりエ ネルギー的に切断を受けやすい部分があり, これが優先的に急速 に反応寸ることも考觉られる．初期に起こる急速な反応がこの種 の異常現象ならば，これに引き続いて起こる反応が本来の特性と いうことになるであろう．また，他の考方方として分子内の特別 な部分ではなく試料中に溶存している徵量の酸素分子により, 活 性なペルオキシラジカルが発生し, 反応が促進されることも充分 考兄られる。

熱劣化による影響を調べる目的でゲル化した試料抏よび劣化前 の試料の赤外吸収スペクトルを調べたところ，酸化物に特有とさ れる一 $\mathrm{OH}\left(3420 \mathrm{~cm}^{-1}\right)$ および $\mathrm{C}=\mathrm{O}\left(1720 \mathrm{~cm}^{-1}\right)$ の吸收 ${ }^{11)}$ は汪 とんど検出されず, この実験条件では酸素が主体となる劣化反応 は起こっていないと推測される.

赤外吸收スペクトルの測定結果から, 熱劣化に伴う cis から trans 構造への 異性化現象が観察された。すなわち， $735 \mathrm{~cm}^{-1}$, $911 \mathrm{~cm}^{-1}, 967 \mathrm{~cm}^{-1}$ に現れる cis 1,2 扤よび trans の吸収から

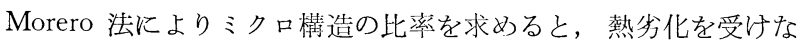
い試料では trans 構造が $2 \%$ 程度であるが，その比率は約 $200^{\circ} \mathrm{C}$

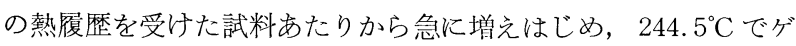
ル化したものは約16\%近くに達する。この場合 1,2 粠造の含量は ほとんど変わらないようである。このことから Arrhenius プロッ

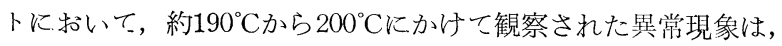

Table 2 Swelling ratio $Q$ and sol fraction of the heat treated sample. Swelling condition:temperature, $30^{\circ} \mathrm{C}$;time, $48 \mathrm{hrs}$; solvent, benzene

\begin{tabular}{clrr}
\hline Sample & Temp. & Q(\%) & Sol $(\%)$ \\
\hline 1 & 142.5 & - & 100 \\
2 & 158 & 8442 & 39 \\
3 & 165 & 7856 & 41 \\
4 & 193 & 5915 & 31 \\
5 & 199 & 3280 & 28 \\
6 & 200 & 2839 & 17 \\
7 & 211.5 & 1182 & 9 \\
8 & 220 & 828 & 4 \\
9 & 244.5 & 646 & 1 \\
\hline
\end{tabular}

ゲル化や鎖切断だけではなく熱による異性化現象が関係する可能 性もある。

熱によりゲル化した試料を，30ㄷのベンゼン中で48時間膨潤さ せた結果をTable 2 に示した. $140^{\circ} \mathrm{C} か ら 150^{\circ} \mathrm{C}$ にかて急速にゲ ル化反応がはじまるが, 膨潤度は通常のイオウなどを用いた場合 に比してかなり大きい。

\section{4. 結}

\section{論}

1）短時間領域に打ける応力緩和測定により, 物理緩和のみを単 離することができる. 熱劣化挙動を調べる場合, 物理緩和と化 学緩和とを完全に分離しうるので有効な方法である.

2）未架橋ポリブタジェンは熱によりゲル化するが，ゲル化反応 が初期の極めて速いものと, その後の比較的遅いものとに分け られる。

3）ゲル化の活性化エネルギーは, 観測時間依存性を有し速い反 応と遅い反応で，それぞれ約 24〜36, 0〜 $5 \mathrm{kcal} / \mathrm{mol}$ 程度であ る.

（昭和53年10月26日 第26回レオロジー討諭会で講演）

\section{引用 文 献}

1) Tobolsky, A.V., I.B. Prettyman, and J.H. Dillion, $J$. Appl. Phys., 15, 324, 380 (1944).

Tobolsky, A.V., "Properties and Structure of Polymers", Chap. 5 (1960), John Willey \& Sons, N.Y.

2）村上謙吉，日本ゴム協会誌，50，386 (1977). 村上謙吉，高杉純生，同上，50，65 (1977).

3）村上謙吉, 中西啓真, 日本レオロジ一学会誌, 5, 3 (1977).

4) Veith, A.G., J. Polym. Sci., 25, 355 (1957).

5) Arai, K., R.P.P.P.J., 20, 317 (1977).

6) Dunell, B.A., and J.H. Dillon, Text. Res. J., 21, 393 (1951).

7) Watson, M.T., W.D. Kennedy, and G.M. Armstrong, J. Appl. Phys., 26, 701 (1955).

8）栗原福次, 小林隆, 石川一男, 日本ゴム協会誌, 38, 569 (1965).

9）山下晋三，日本ゴム協会誌， $42 ， 661$ (1969)； 36, 883 (1963).

10）村上謙吉, 草野孝衛, 中村茂夫, 木瀬秀夫, 小野勝道, 工 化誌, 70, 188 (1967).

11) Rugg, F.M., J.J. Smith, and R.C. Bacon, J., Polym. Sci., 13, 535 (1954). 